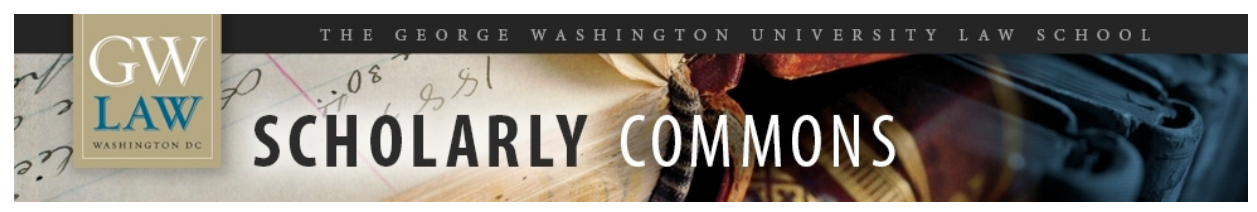

\title{
A Historical Perspective on Parental Alienation Syndrome and Parental Alienation
}

Joan S. Meier

George Washington University Law School, jmeier@law.gwu.edu

Follow this and additional works at: https://scholarship.law.gwu.edu/faculty_publications

Part of the Law Commons

\section{Recommended Citation}

Joan S. Meier, A Historical Perspective on Parental Alienation Syndrome and Parental Alienation, $6 \mathrm{~J}$. Child Custody 232 (2009).

This Article is brought to you for free and open access by the Faculty Scholarship at Scholarly Commons. It has been accepted for inclusion in GW Law Faculty Publications \& Other Works by an authorized administrator of Scholarly Commons. For more information, please contact spagel@law.gwu.edu. 
This article was downloaded by: [Leslie M. Drozd, Ph.D.]

On: 20 August 2009

Access details: Access Details: [subscription number 910268035]

Publisher Routledge

Informa Ltd Registered in England and Wales Registered Number: 1072954 Registered office: Mortimer House, 37-41 Mortimer Street, London W1T 3JH, UK

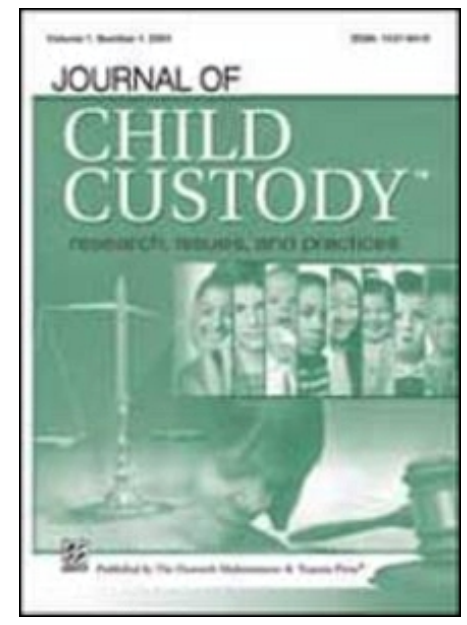

\section{Journal of Child Custody}

Publication details, including instructions for authors and subscription information:

http://www.informaworld.com/smpp/title content=t792306888

\section{A Historical Perspective on Parental Alienation Syndrome and Parental}

\section{Alienation}

Joan S. Meier a

a George Washington University Law School, Washington, DC

Online Publication Date: 01 July 2009

To cite this Article Meier, Joan S.(2009)'A Historical Perspective on Parental Alienation Syndrome and Parental Alienation',Journal of Child Custody, 6:3,232 - 257

To link to this Article: DOI: $10.1080 / 15379410903084681$

URL: http://dx.doi.org/10.1080/15379410903084681

\section{PLEASE SCROLL DOWN FOR ARTICLE}

Full terms and conditions of use: http://www.informaworld.com/terms-and-conditions-of-access.pdf

This article may be used for research, teaching and private study purposes. Any substantial or systematic reproduction, re-distribution, re-selling, loan or sub-licensing, systematic supply or distribution in any form to anyone is expressly forbidden.

The publisher does not give any warranty express or implied or make any representation that the contents will be complete or accurate or up to date. The accuracy of any instructions, formulae and drug doses should be independently verified with primary sources. The publisher shall not be liable for any loss, actions, claims, proceedings, demand or costs or damages whatsoever or howsoever caused arising directly or indirectly in connection with or arising out of the use of this material. 


\title{
A Historical Perspective on Parental Alienation Syndrome and Parental Alienation
}

\author{
JOAN S. MEIER \\ George Washington University Law School, Washington, DC
}

\begin{abstract}
Claims of parental alienation syndrome (PAS) and parental alienation (PA) have come to dominate custody litigation, especially where abuse is alleged. Although much psychological and legal literature has critiqued PAS, and leading researchers as well as most professional institutions have renounced the syndrome concept, alienation as a parental behavior or child's condition continues to be extensively investigated and credited in research and forensic contexts. This article reviews the history of PAS, both as posited by its inventor, Richard Gardner, and as used and applied in courts, suggesting that it not only lacks empirical basis or objective merit, but that it derives from its author's troubling beliefs about adult and child sexual interaction. It then examines the more recent explorations of non-syndrome "alienation" as proffered by Janet Johnston and others, noting both its more balanced and grounded nature and its more modest remedial implications. However, the article concludes that $P A$ is too closely tied to PAS to be an adequate improvement. It, too, is used crudely in courts to defeat abuse allegations, it continues to rely on speculations about mothers' purported unconscious desires and their effects on children, and, more subtly than PAS, it minimizes abuse and its effects on mothers and children. At root, although even $P A$ researchers have found it to be a real issue in only a small minority of contested custody cases, courts' and evaluators' extensive focus on it in response to mothers' abuse allegations continues to privilege false or exaggerated alienation concerns over valid concerns about abuse.
\end{abstract}

KEYWORDS abuse, parental alienation, PAS

Address correspondence to Joan S. Meier, Esq., Professor of Clinical Law, Director, Domestic Violence Legal Empowerment and Appeals Project, George Washington University Law School, 2000 G St. N.W., Washington, DC 20052. E-mail: jmeier@law.gwu.edu 
In a surprisingly brief time, parental alienation - the theory that children in divorcing families may be turned against one parent by the other favored parent-has come to dominate the discourse in many family courts, while deeply dividing lawyers and psychologists who work with parents and children in contested custody litigation. However, whereas scientific and clinical critiques and defenses of parental alienation theories exist, relatively little attention has been paid to the historical and advocacy context within which parental alienation has emerged as a primary focus of family courts. This article offers a historical perspective on the development and uses of alienation claims in family court. This context highlights the dubious pedigree of alienation theory and the resulting problem with attempting to define a legitimate place for this concept in custody litigation. ${ }^{1}$

\section{THE HISTORY OF PARENTAL ALIENATION CLAIMS IN CUSTODY COURTS}

\section{Pre-Gardner}

The notion that divorcing parents, or parents battling custody, might encourage their children to choose sides against their ex was, and is, hardly new (Myers et al., 2002). (Indeed, this happens in intact families too.) Custody-contesting parents have probably always run the gamut from those who have taken the high road and sought to protect their children from their own conflict, to those who have actively enlisted the children in their battles against the other parent. However, one population in particular stands out as aggressively denigrating the other parent in the eyes of the children: male abusers. ${ }^{2}$

It is well-established that an abuser's active undermining of his partner's authority and competence to parent is one of the most common and most destructive elements of the abusive relationship (Bancroft \& Silverman, 2002; Dalton, Carbon, \& Olesen, 2003; Drozd \& Olesen, 2004). For instance, it is common for abusers to berate and attack the mother in front of the children, to criticize her inadequacies as a homemaker, to call her names, and curse her in front of the children. It is also common for abusers to criticize her as a person, to encourage the children not to obey her, and to take active steps to undermine her activities with the children such as denying her money to take them places or keeping her from leaving the house to attend children's school or athletic functions. An abuser will often blame his own failings on her (e.g., telling the children that it is her fault that he cannot see them more often, they cannot go to a movie, that she failed to tell him about an event, that there is not enough money in the house), and he will generally insult and undermine her parenting (Dalton, Carbon, \& Olesen, 2003; Stark, 2007a). In fact, batterers' undermining of mothers' authority is often so pronounced that two leading specialists in batterers' intervention 
and abuse and custody evaluation state that "the preponderance of our clients augment the inherently undermining effects of battering with deliberate tactics designed to control the children's loyalties and to govern their perceptions" (Bancroft \& Silverman, 2002, p. 59).

Two examples from my own and a colleague's caseload, might suffice here:

The batterer would make the children come out of their rooms to watch him beat their mother, while explaining to the children "this is how you treat whores and sluts."

The batterer would tell the children in front of the mother, "If you come home and your mother isn't here, she will be buried out back by the dog." (Stark, 2007a)

Batterers' vendettas against their children's mothers are also often played out in aggressive litigation against her, especially over custody. Custody litigation is an "ideal" mechanism for denigrating the mother by providing a forum for attacks on her dignity and competence as a mother while enlisting court personnel to join the attack (American Psychological Association [APA], 1996; Dalton, Carbon, \& Olesen, 2003; Stark, 1995). Moreover, many mothers view losing custody - especially to their abuser - as the worst that could happen to them. When abusers do receive custody, as is becoming more common, they have thereby succeeded in inflicting a profound injury on the mother. The legal system's imprimatur of legitimacy on her abuser and rejection of her as a parent exacerbates the harm (Herman, 1992). Finally, in a significant number of cases, abusers with custody have succeeded in completely ending the mothers' contact with their children pursuant to court order (Neustein \& Lesher, 2005; Stop Family Violence, 2007). Such a complete deletion of a mother-child relationship would seem to be the epitome of destructive "parental alienation" (while admittedly accomplished by judicial action).

Given the degree to which abusers utilize alienating behaviors to undermine mothers' relationships with their children, a Martian who had just landed on earth might ask why advocates for domestic violence victims are so hostile to the theory of parental alienation: Is it not exactly what batterers have been doing all these years, and is it not a bad thing? Yes, and yes, but that is not how alienation theory was derived, propounded, or implemented. Instead, alienation theory's traction in family courts is fueled by the denial of abuse; it is used to refute mothers' claims of paternal abuse and almost never to recognize the emotional abuse many abusers inflict on their children.

Indeed, in this author's and others' experience, courts have been largely indifferent to what batterers do to denigrate mothers. In cases such as those 
described above, courts typically responded to my requests that an abuser be prohibited from derogating the mother to the children merely by issuing a mutual order that "neither parent shall speak negatively about the other in front of the children." The batterer's active and egregious undermining of the mother's authority and relationship with the children would be given no serious consideration in determining his parental rights. Rather, it was seen as par for the course among adversarial parents, a transient problem and a mutual one, and one that did not go to the ultimate question of the children's best interests regarding parenting rights. I suspect that this is how custody courts always treated one parent's denigration of the other until Gardner's PAS came along (Gardner, 1992a, 1992b). Gardner invoked alienation - and marketed it widely - as a means of refuting mothers' claims of abuse. Then, and only then, did courts take notice.

\section{Gardner's PAS}

The phenomenon of a child's rejection of a parent and strong resistance or refusal to visit which has been tied to a pathological alignment between an angry parent and the child, was first identified by divorce researchers Wallerstein and Kelly (1976, 1980). In their theory, this unhealthy "alignment" was seen primarily in older children or adolescents, and it stemmed from the dynamics of the separation, including the child's reaction to the divorce. While this construct was not insignificant, it did not at that time become a staple of custody evaluations or judicial determinations. Wallerstein and Kelly also focused more on the children's alignment with one parent than with that parent's active and intentional alienation of the children from the other.

Enter Richard Gardner. In the 1980 s, while lawyers such as myself were trying to persuade courts to recognize the dangerousness and destructiveness to the children of our clients' abusive ex-partners, Gardner toiled in his own garden of clinical practice counseling divorcing parents and published a series of books and articles about divorce and child custody. Gardner's portfolio is quite extensive, and some of his early work was valuable, possibly lending credibility to his subsequent invention of the "parental alienation syndrome" (PAS). ${ }^{3}$ Based solely on his interpretation of his own clinical experience, Gardner posited that child sexual abuse allegations were rampant in custody litigation, and that $90 \%$ of children in custody litigation are suffering from the PAS "disorder." He described PAS as a "syndrome" whereby vengeful mothers employ child abuse allegations as a "powerful weapon" to punish the ex and ensure custody to themselves (Gardner, 1992a, 1992b). He further theorized that such mothers enlist the children in their "campaign of denigration" and "vilification" of the father, that they often "brainwash" or "program" the children into believing untrue claims of abuse by the father, and that the children then would fabricate their own added stories (Gardner, 
1992b, p. 162, 193; 2002, pp. 94-94). He claimed-based solely on his own clinical practice - that the majority of child sexual abuse claims in custody litigation are false (Gardner, 1991), although he suggested that some mothers' vendettas are the product of mental illness rather than intentional malice (Gardner, 1987, 1992b). Gardner posited that when children reject their father and abuse allegations are made, this behavior is most likely the product of PAS rather than actual experiences of abuse. PAS theory recasts abuse claims as false tools for alienation, thereby inherently dissuading evaluators and courts from serious consideration of whether abuse has actually occurred.

The critiques of Gardner's PAS are legion, focusing on its circularity, its lack of empirical basis, and Gardner's bizarre beliefs about human sexuality.

Circularity. Perhaps the most salient critique is the most obvious: It is self-referential and conclusory. Gardner (Gardner, 1992a) posited that most child sexual abuse claims in custody litigation are false, and, that where they exist, PAS typically exists. However, while acknowledging that if the abuse was real there could be no PAS, Gardner largely sidesteps the fundamental question of whether and how courts should determine the truth of the abuse claims. Thus, his "diagnostic criteria" for differentiating between "fabricated" and "bona fide" abuse focus almost entirely on various (subjective) personality characteristics of the parties rather than expert assessments of abuse itself, or the many other reasons that might explain a child's hostility toward a parent during a divorce (Gardner, 1992b; see also Hoult, 2006). Moreover, even the assessment he does recommend is itself circular: Gardner (1987) identifies "the presence of the Parental Alienation Syndrome" itself as an "extremely valuable differentiating [criterion]" for distinguishing between true and false claims of abuse (p. 109). In other words, in Gardner's world, to determine whether there is PAS, we must determine if the abuse claims are valid; yet, in order to determine if the abuse claims are valid, we are invited to first decide that there is PAS.

It is this kind of circularity and conclusory reasoning that gives weight to the common accusation that PAS theory simply presumes that a child's hostility toward a father is pathological and that mothers who make such allegations are doing so only to undermine the child's relationship with the father. These powerfully chilling presumptions cause many valid child abuse claims not to be seriously investigated and instead to be turned against the mother who alleges them. The disbelief of child sexual abuse allegations is consistent with Gardner's intention in propagating the PAS theory. It is reflected in Gardner's recorded statement (in a filmed interview) (Waller, 2001) that when a child tells her mother she has been sexually molested by her father, the mother should respond, "I don't believe you. I'm going to beat you for saying it. Don't you ever talk that way again about your father." 
Empirical Premises are False. Gardner invented PAS in response to two purported phenomena: (a) widespread use of child sexual abuse allegations in custody cases, and (b) his belief that allegations in that context have a "high likelihood of being false" (Gardner, 1991, 1992b). Neither quantitative claim has any empirical basis other than Gardner's assertions based on his own clinical experience, with a practice that attracted clients who knew his views - and Gardner's own attitude toward child abuse claims, as shown previously, which involved extreme skepticism. Contradicting his claims are the results of the largest ever study of child sexual abuse allegations in custody litigation consisting of over 9000 cases in 12 jurisdictions. This study (Thoennes \& Tjaden, 1990) found that child sexual abuse allegations were extremely rare (less than $2 \%$ of cases) and that approximately $50 \%$ of the claims were deemed valid, even by the normally quite conservative court and government-affiliated evaluators. Other studies (Faller, 1998) have found such allegations to be validated approximately $70 \%$ of the time. Indeed, leading researchers (Trocme \& Bala, 2005) have found, contrary to the conventional wisdom that child sexual abuse is a common form of false allegation in custody litigation, and that "high rates of unsubstantiated maltreatment" in "circumstances that indicat[e] that abuse or neglect may have occurred" are a bigger problem than false claims of child sexual abuse (pp. 1342-44). Nonetheless, Gardner's empirical claims of a flood of false abuse allegations have powerfully influenced custody courts and forensic evaluators. It is virtually an article of faith in these venues that child sexual abuse in particular, and abuse in general, are widely and falsely alleged by mothers in custody litigation (Alford, 2003; Pearson, 1993).

Gardner's Beliefs. Gardner's passionate propagation of the PAS theory with little objective basis for it may be more comprehensible in light of his larger framework of beliefs about human sexual behavior. His writings on this subject are in fact so extreme that it is doubtful that courts would have adopted his theory of PAS if they were aware of his beliefs. For instance, his writings (Gardner, 1992b) express the view that all human sexual paraphilias (deviant behaviors) "serve the purposes of species survival" by "enhanc[ing] the general level of sexual excitation in society" (p. 20; see also Hoult, 2006). These sexual behaviors include pedophilia, sadism, rape, necrophilia, zoophilia (sex with animals), coprophilia (sex with feces), and other paraphilias (Gardner, 1992b; see also Dallam, 1998; Hoult). Further, Gardner claimed that women's physiology and conditioning makes them potentially masochistic rape victims who may "gain pleasure from being beaten, bound, and otherwise made to suffer," as "the price they are willing to pay for gaining the gratification of receiving the sperm" (Gardner, 1992b, p. 26). Regarding pedophilia itself, Gardner (1992b) argued expressly that adult-child sex need not be intrinsically harmful to children. He claimed that adult-child sex is beneficial to the species, insofar as it 
increases a child's sexualization and increases the likelihood that his or her genes will be transmitted at an early age (Gardner, 1992b). Contrary to his own claim that most sexual abuse claims in the context of custody disputes are false, Gardner also claimed, with equal lack of basis, that "probably over 95\%" of all (non-litigation) sex abuse allegations are valid because "sexual activities between an adult and a child are an ancient tradition," a "worldwide phenomenon," and have "been present in just about every society studied, both past and present" (Gardner, 1992b, pp. 47-48). Gardner viewed western society as "excessively punitive" in its treatment of pedophilia as a "sickness and a crime" (Gardner, 1991, p. 115). He attributed this Western "overreaction" to the influence of the Jews (Gardner, 1992b). Gardner opposed mandated reporting of child sexual abuse, and specifically described a case in which he successfully persuaded a mother not to report a bus driver who had molested her daughter. He contended that reporting the molestation would "interfere with the natural desensitization process, would be likely to enhance guilt, and would have other untoward psychological effects" (Gardner, 1992b, pp. 611-12; see also Dallam). Gardner's perspective on adult-child sexual interaction can be summed up in his reference to Shakespeare's famous quote: "There is nothing either good or bad, but thinking makes it so'" (Gardner, 1991, p. 115).

Consistent with Gardner's views of women's sexuality, his explanations for why PAS occurs were, in equal part, bizarre and offensive. Among other things he explained mothers' fabrications of such egregious claims by invoking the biblical phrase, "hell hath no fury like a woman scorned" and suggested that some women are titillated by imagining their child having sex with the father (Gardner, 1987, 1992a). Needless to say, there is no empirical basis or support for these assertions.

Proposed Remedies for PAS. Gardner's "remedies" for "severe PAS" are draconian and extreme and include total cut-off of the child's contact with the mother, as well as, "de-programming" the child through a concerted brainwashing effort to change the child's beliefs that they have been abused (Bruch, 2001; Gardner 1992a). Even putting aside the "tyrannical" quality of such proposals (Johnston \& Kelly, 2004a), they can be more traumatic than the ills they purport to cure. In more than one case children subjected to these procedures have become suicidal - and in some cases died-in reaction to court orders to live with the father they believed abused them (Bruch; Hoult, 2006). In other cases, courts have ordered children into jail and juvenile homes as part of the "threat therapy" Gardner recommended, which is a stock in trade of strict alienation psychologists (Hoult; Johnston \& Kelly, 2004a). In one such case:

A judge ordered a frail 9 year old boy seized by three police officers and placed in a juvenile detention facility when he refused to get into his 
father's car for a scheduled visitation. The son of the father's girlfriend had sexually abused the boy, and he had also witnessed the father's violence against his mother. After three days of abuse by the other boys in the detention facility, the boy agreed to cooperate with the court order. The judge concluded that his "treatment" for parental alienation had worked (Stark, 2007a).

Lack of Scientific Validity. The dominant consensus in the scientific community is that there is no scientific evidence of PAS. PAS is a label that offers a particular explanation for a breach in relationship between a child and parent, but insofar as that breach could be explained in other ways, it is not in itself a medical or psychological diagnosis so much as a particular legal hypothesis (Hoult, 2006). While clinicians frequently insist that they often see "alienation" in their caseloads (Johnston \& Kelly, 2004b), there is no objective way to verify whether the relationship breaches they observe are caused by an alienation "disorder" as opposed to a "healthy response" to a destructive or disconnected parent. Even leading alienation researchers have rejected the scientific validity of PAS (Johnston \& Kelly, 2004a).

The complete absence of scientific evidence of PAS has convinced not only a Presidential Task Force of the American Psychological Association (APA, 1996) but also many otherwise sympathetic researchers and evaluators to conclude that "the scientific status of PAS is, to be blunt, nil." (Emery, Otto, \& O’Donohue, 2005; see also Gould, 2006; Ducote, 2002; Wood, 1994). Statements such as this are not uncommon: "PAS as a scientific theory has been excoriated by legitimate researchers across the nation. Judged solely on his merits, Dr. Gardner should be a rather pathetic footnote or an example of poor scientific standards" (Bruch, 2001, quoting Paul Fink, past President of American Psychiatric Association, citation omitted).

Echoing the scientific consensus, a leading judicial body, the National Council of Juvenile and Family Court Judges (NCJFCJ) has published Guidelines (as cited in Dalton, Drozd, \& Wong, 2nd ed. 2006, p. 24) for custody courts stating that "The theory positing the existence of 'PAS' has been discredited by the scientific community. Any testimony that a party to a custody case suffers from the syndrome or 'parental alienation' should therefore be ruled inadmissible and/or stricken from the evaluation report." Numerous other legal experts have joined the chorus. The Sexual Abuse Legitimacy Scale (SALS), on which PAS is partly based, has been called "probably the most unscientific piece of garbage I've seen in the field in all my time. To base social policy on something as flimsy as this is exceedingly dangerous" (Bruch, 2001, quoting expert Professor Jon Conte, citation omitted). "Although PAS may be hailed as a 'syndrome'... in fact it is the product of anecdotal evidence gathered from Dr. Gardner's own practice.... PAS is based primarily upon two notions, neither of which has a foundation in empirical research" (Ragland \& Fields, 2003a, p. 1). "PAS is an unproven 
theory that can threaten the integrity of the criminal justice system and the safety of abused children" (Ragland \& Fields, 2003b, p. 4).

\section{Courts' Response to PAS}

Despite the palpably extreme and unbalanced quality of both the PAS theory and the thinking of its author, as well as the lack of scientific basis, the theory has for over a decade become virtually ubiquitous in family courts. The prevalence of PAS in courts is particularly puzzling in light of the fact that not one precedential decision has found it admissible under evidentiary standards for admitting scientific evidence. Indeed, the only three published court opinions actually analyzing and adjudicating the legal admissibility of PAS (one each in criminal court, family court, and a civil tort case) found that its lack of scientific validity meant it did not meet legal standards for admissibility (N.K. v. M.K., 2007; People v. Fortin, 2001; Snyder v. Cedar, 2009; see also Hanson v. Spolnik, 1997 (dissent)). ${ }^{4}$ Other courts have questioned its admissibility (C.J.L. v. M.W.B., 2003; In re Interest of T.M.W., 1989; People v. Sullivan, 2003) or its legitimacy (C.J.L. v. M.W.B., 2003; In re J.C., 2007). Nonetheless, it has come to dominate custody litigation, particularly when child or adult abuse is alleged (APA, 1996; Bruch, 2001; Hoult, 2006; Wood, 1994).

To a troubling degree, family courts and even courts of appeal are increasingly accepting the application of PAS or PA findings while sidestepping the admissibility question (Faucherv. Bitzer, 2002; Ignatiuk v. Ignatiuk, 2006; In re Marriage of Arthur, 2004; In re Marriage of Bates, 2004; In re Marriage of McCord, 2003; In re Marriage of Rosenfeld, 1994; J.F. v. L.F., 1999; Linder v. Johnson, (2006); Palazzolo v. Mire (2009); Ruggiero $v$. Ruggiero, 2003). PAS' application also has not been limited to the original context for which it was invented: child sexual abuse allegations and cases where children refuse to visit their father. Rather it is routinely invoked whenever any kind of abuse is raised and/or a mother seeks to restrict a father's visitation (Hoult, 2006, n. 172; J.F. v. L.F., 1999; Wiederholt v. Fisher, 1992; Linder v. Johnson, 2006; Sharp v. Keeler, 2007). In one case I litigated where the mother was alleging domestic violence, the children all wanted to visit the father but did not want him to have shared custody. Because the mother opposed joint custody, was alleging abuse, and had been witnessed making one remark about not wanting to go to a child's event if the father was going to be there, the evaluator found PAS, causing the case to revolve around whether the mother was undermining the children's relationship with their father (Licata, v. Licata, 2003). ${ }^{5}$

To a great extent, the influence of PAS thinking on custody courts has been driven by the neutral "allied" professionals who serve such courts, including custody evaluators, other forensic evaluators, and guardians ad litem (GALs) (Ducote, 2002; Meier, 2003; Smith \& Coukos, 1997). While some 
judges already may be predisposed to skepticism about abuse claims in custody litigation, "expert" opinions from neutral psychologists or GALs invoking purportedly scientific concepts can powerfully influence genuinely inquiring courts, even where such expert opinions actually lack genuine scientific basis (Emery et al., 2005; Shuman, 2002). A case in point is one I recently litigated in the District of Columbia (Wilkins v. Ferguson, 2007). The court originally found "inappropriate touching" of the child by the father, based primarily on testimony by a physician and social worker from a Children's Hospital with a substantial reputation in child abuse evaluation and treatment. However, after the court's forensic evaluator-who observed a single positive court-supervised visit between the child and her fathernoted the purported prevalence of false child sexual abuse claims in "high conflict" custody litigation and posited the possibility of parental alienation, the judge essentially reversed himself and reinstated unsupervised visitation. This was remedied on appeal (i.d.).

The rare appellate opinion provides a troubling window into the ways evaluators and courts are employing PAS as the easy answer to abuse allegations by children and their protective parent's efforts to keep them safe. In Linder v. Johnson (2006), the Arkansas Court of Appeals declined to address PAS' validity or admissibility, but it affirmed the diagnosis and transfer of custody to the father despite the children's expressed fear for their lives and threats to run away. The PAS psychologist had characterized the children's abuse allegations as "preposterous" and their "lack of ambivalence toward their father" as "unnatural, if not absurd" (Linder v. Jobnson, p. 23). The Appellate Court - affirming the trial court's rejection of the other psychologist who believed the children's claims of abuse and stated that custody to the father would be the "worst thing that could happen" to the children (i.d. at 29) — stated that the alienation finding was "supported" by the "evidence" that the children and the mother made the same allegations of abuse (Linder $v$. Johnson, p. 29). In another case, the appellate court affirmed the trial court's transfer of custody to a father, approving, among other things, the finding that a mother who responded to her 11-year-old daughter's "cry for comfort" by visiting her at the school after-care program before the father's family picked her up for his visit, was an example of the mother's "interference and her attempts to sabotage the children's relationship with their father" (Faucher v. Blitzer, 2002, p. 3).

In Arkansas, as is true in some other small states, the same one or two psychologists were responsible for the substantial number of PAS opinions issued by that appellate court (Faucher v. Blitzer, 2002; Linder v. Johnson, 2006; Turner v. Benson, 1997). Psychologists such as this who specialize in PAS seem inclined to find PAS wherever children and their mothers allege child abuse and resist unfettered access by the accused father. What is more troubling, one or two individual psychologists can also single-handedly create "law" for the state. 
In short, the "success" of the PAS theory-of course compounded by other parallel trends including the strong judicial preference for joint custody-in turning courts against mothers claiming abuse has been little short of amazing. Although in the past, the credibility of an abuse claim was always an implicit concern in custody litigation, now, such claims are automatically treated as highly suspect and either trivialized as "not uncommon in a divorce dispute" with "high conflict" or treated as evidence of alienation (Alford, 2003; Faucher v. Bitzer, 2002; Linder v. Johnson, 2006; see also Dalton, 2003; Bancroft \& Silverman, 2002). The fact that PAS lacks any empirical basis and that comprehensive empirical research has consistently refuted the myth of widespread sexual abuse allegations in custody litigation (Pearson, 1993; Thoennes \& Tjaden, 1990; Trocme \& Bala, 2005) does not appear to have penetrated family courts. ${ }^{7}$ Instead, abuse lawyers and their clients now typically face significant hurdles in custody litigation including the assumptions that (a) mothers' rejection of shared custody is highly suspect; (b) vengeful mothers often seek to exclude fathers from children's lives; (c) fathers who contest custody do so out of paternal affection and concern; (d) adult abuse allegations are minimally relevant to children's welfare; (e) mothers frequently fabricate or exaggerate other abuse allegations in order to gain an advantage in custody litigation; and (f) child sexual abuse allegations are used by mothers as an outrageous "bombshell" (Bancroft \& Silverman, 2002; Stop Family Violence, 2007; Neustein \& Lesher, 2005). Many of these assumptions are fueled not only by PAS theory but also by courts' deep preference for paternal involvement in children's lives postdivorce, (Meier, 2003). However, PAS theory has paved the way for courts' elevation of this preference even over safety concerns. Indeed, anecdotally, PAS appears to be facilitating courts' imposition of shared or sole paternal custody even in the face of findings or admissions of some degree of family violence (see Titelman and Stockhome sections of Stop Family Violence, 2007; Oates v. Oates, 2008; Rebarv. Ghaben, 2008). In such cases, PAS serves to counter or neutralize the acknowledged abuse by providing an equally or more negative label for the mother. Insofar as committing domestic violence in the child's presence is a form of psychological abuse or neglect of a child (Lewis-O'Connor, Sharps, Humphreys, Gary, \& Campbell, 2006), this use of PAS may contradict Gardner's own admonition that where the child has been abused or neglected, justifying his or her estrangement, there can be no PAS (Gardner, 1992a).

As a quantitative matter, while no definitive empirical research exists, several surveys have found high (46-70\%) rates of awards of custody (sole or joint) to abusive fathers ${ }^{8}$ (Arizona Coalition Against Domestic Violence, 2003; Massachusetts Supreme Judicial Court, 1990; Meier, 2003; Silverman et al., 2004). It is not known to what extent PAS was alleged in the cases in these surveys, yet the trend toward awarding custody to batterers is certainly consistent with PAS proponents' predisposition to believe that most 
custody-litigating mothers' abuse claims are false. Many, such as myself, who work in the field of custody and abuse are besieged weekly by desperate calls from mothers who have lost or face the likely loss of custody to alleged abusers due to accusations of PAS (see Stop Family Violence, 2007; Lesher \& Neustein, 2006; www.batteredmotherscustodyconference.org; http://www. leadershipcouncil.org/1/pas/dv.html; www.justiceforchildren.org). In the majority of these cases, fallacious psychological or custody evaluations and PAS opinions contribute to courts' dismissing the abuse claims and characterizing the protective mother as an alienator. One of the only published empirical studies of courts' punitive responses to protective mothers documented 300 cases in which purportedly protective mothers were forced either to share custody or to permit their children unsupervised visits with allegedly sexually abusive fathers; in $20 \%$ of the cases the mothers lost custody altogether, and many of these also lost all visitation rights. (Neustein \& Goetting, 1999). Another research study has found that roughly three quarters of mothers who reported child abuse lost custody to the alleged abuser and almost half were accused of PAS (Stahly et al., 2004). Ironically, many such cases have resulted in the total estrangement of the child from the mother in the name of PAS prevention (Stop Family Violence, 2007; Neustein \& Lesher, 2005).

The obvious question is why courts and evaluators have been so receptive to PAS as a theory, given its lack of validity. One answer is that it provides an appealing alternative explanation for the prevalence of abuse claims in custody litigation. Herman (1992) and others have powerfully explicated the tendency of society in general, and courts in particular, to resist knowing about abuse in general, and child sexual abuse in particular:

The knowledge of horrible events periodically intrudes into public awareness but is rarely retained for long. Denial, repression, and dissociation operate on a social as well as an individual level (Herman, 1992; Finkelhor, 1986).

As Herman (1992) says, "the ordinary response to atrocities is to banish them from consciousness." Abuse is horrible to think about, and it is (or should be) difficult to accept that so many men are so violent and abusive to their partners and children. Many judges and evaluators find it easier to believe that many women in custody litigation are lying or disordered. ${ }^{9}$ Although the consistent data indicate that the majority of litigated, contested custody cases (a tiny proportion of all divorcing families) do involve a history of some partner violence, (Jaffe, Crooks, \& Poisson, 2003; Johnston, 1994; Johnston \& Campbell, 1988), courts still harbor the mistaken belief that most abuse allegations in custody litigation are fabricated. ${ }^{10}$

Moreover, some degree of at least implicit gender bias cannot be ruled out. Court-sponsored gender bias studies have repeatedly found that state 
courts do, in fact, treat male and female litigants (and sometimes counsel) differently and that domestic violence allegations are intrinsically gendercharged (Czapanskiy, 1993). In one pair of Arkansas cases (Sharp v. Keeler, 2007), the almost transparent gender bias of the court (which penalized the mother for purported alienation by switching custody to the father but then failed to do the same when the father engaged in more damaging alienating conduct) stimulated outraged dissents by two appellate justices. (I am currently involved in a case in which the abuser was given custody and has turned the teenage children entirely against their mother to the point of expressing intense hatred and adamantly opposing any contact. In stark contrast to the near universality of alienation claims when mothers seek to restrict fathers' access, alienation has yet to be explicitly "diagnosed" or addressed by any of the multiple neutral mental health professionals in the case. ${ }^{11}$ ) When one compares courts' and evaluators' harsh treatment of women believed to be committing alienation (Neustein \& Lesher, 2005) with the fairly benign treatment of men found to have committed some kind of physical or sexual abuse (Meier, 2003), the gender inference is difficult to avoid.

Gender bias may or may not be behind another widespread belief - that whether or not alienation is a "syndrome," it is surely a factual behavior that many women engage in. Whenever I mention this topic to acquaintances, they regale me with a story of someone they know who engaged in ugly conduct to restrict her ex-husband's rights to the children. Notably, not one of those stories (in this admittedly unscientific sample) has included allegations of abuse. Nonetheless, the widespread belief (and perhaps experience) that divorcing women do wrongfully undermine fathers' relationships with children makes acceptance of the PAS theory an all too easy leap.

Finally, and perhaps most sympathetically, the receptivity to alienation theories reflects the degree to which an overriding belief in the importance of fathers - and shared parenting - shapes and dominates the psychological professions, courts, and even to some degree, the public. The importance of "shared parenting" tends to lead almost any family court discussion of custody (Steinberger, 2006). It is an article of faith of most family courts and evaluators - despite continued debate about the empirical support - that children need "frequent and regular" contact with both parents for optimal psychological health (Daghir v. Daghir, 1981, 1982; Tanfer \& Mott, 1997; www.thelizlibrary.org/liz/those-jointcustody-studies.html). In this respect, the fathers' rights movement has been remarkably successful. Even a glance at leading newspapers demonstrates a fascination with fathers and fathering, and a comparative lack of interest in, or respect for, mothers and mothering. (USA TODAY Snapshots, 2007; Boorstein, 2006; Harris, 2006; Barr, 2006; Montes, 2006; The Washington Post, 2006; Associated Press, 2006). Family courts and state policies also strongly favor shared parenting and father involvement: Twenty three states have adopted legislative preferences for 
joint custody regardless of a party's opposition (see http://www.abanet.org/ domviol/docs/Custody.pdf), but any family lawyer will tell you that even in states that lack such legislation, joint custody is still very strongly preferred and overwhelmingly commonly imposed by courts (Meier, 2003). ${ }^{12}$.

Underlying this emphasis on the importance of fathers is another typically unstated but powerful pair of beliefs: that fathers are "underdogs"and that mothers have an unfair advantage-in custody litigation. These views are deliberately propagated by fathers' rights groups who tout the inaccurate claim that men are routinely unfairly denied custody in court (Leving \& Sacks, 2007; Thompson \& Sacks, 2002; www.fathersandfamilies.org). In fact, empirical research casts significant doubt on the widespread belief-based on outdated norms - that mothers have an advantage in custody litigation. On the contrary, the data that exists indicates that some form of joint custody appears to be the most common outcome of contested custody litigation. Among the exceptions to joint custody, several studies have found that it is fathers, not mothers, who more often win sole custody (Massachusetts Supreme Judicial Court, 1990; Morrill, Dai, Dunn, Sung \& Smith, 2005). ${ }^{13}$ Nonetheless, the view of fathers as the underdogs in custody court persists. Perhaps courts are operating from the (unfounded) assumption that men who fight for custody are particularly dedicated fathers. In equal part, it seems likely that courts lean toward fathers because they mistakenly believe fathers are too often given short shrift as parents. While this may have been true at one time, it is certainly not the case now.

\section{The Move From PAS to Parental Alienation (PA)}

The many critiques of Gardner have resulted in a shift — at least among leading researchers and scholars of custody evaluation - from support for PAS to support for a "reformulation of PAS" typically called instead "parental alienation" or "the alienated child" (Johnston, 2005; Steinberger, 2006). Johnston and Kelly (2004a), along with Drozd and Olesen (discussed in Meier, in press), are among the leading credible researchers spearheading this trend. ${ }^{14}$ Johnston and Kelly have clearly stated that PAS does not exist, that Gardner's version of it is "Overly simplistic" and tautological, and that the data do not support labeling alienation a "syndrome." Instead, they speak of "parental alienation" or "child alienation," as a valid concept that describes a real phenomenon experienced by some children in the context of custody disputes.

What is the difference between PAS and PA? The primary shift in focus appears to be away from Gardner's obsession with the purportedly alienating parent and toward a more realistic assessment of the multiple sources of the child's hostility or fear of his or her parent, including behavior by both parents and the child's own vulnerabilities (Kelly \& Johnston, 2001; Johnston \& Kelly, 2004b; Johnston, 2005). Johnston (2005) defines an alienated child as one "who expresses, freely and persistently, unreasonable negative feelings 
and beliefs (such as anger, hatred, rejection and/or fear) toward a parent that are significantly disproportionate to the child's actual experience with that parent. Entrenched alienated children are marked by unambivalent, strident rejection of the parent with no apparent guilt or conflict" (p. 762).

Another notable difference between PAS and Johnston's reformulated PA is the renunciation of Gardner's draconian and brutal "remedies," including custody-switching to the "hated" parent. Johnston calls instead for individualized assessments of both the children and the parents' parenting, maintaining focus on the children's needs rather than the parents' "rights." Reconciliation with the hated parent is not necessarily the only desirable goal; a more realistic and healthy attitude toward both parents is (Johnston, 2005).

More Similar than Different. The new approach to alienation blunts some of the more extreme elements of Gardner's theory and places the problem of alienation in a more moderate and reasonable light (by recognizing the many reasons children can become alienated from a parent). Nonetheless, because the differences between "alienation" and PAS are not firmly established, many discussions of parental alienation still necessarily draw on PAS theory and scholarship, and, at least in practice, invocations of PA appear often to be simply "old wine in new bottles." Exegeses of parental alienation and its destructive impact on children and their relationships with the "target" parent continue to lend credibility to the view that alienation is a pernicious, significant, but subtly destructive form of emotional child maltreatment. Because such discussions sometimes take pains to indicate that the alienating parent may not be deliberately malicious, but unconsciously alienating, they may soften the demonizing tone of Gardner's most extreme PAS discussions and make alienation a more believable and plausible concept. At the same time, by stressing that alienation can occur through unconscious behaviors or wishes, they reinforce the pathologizing of mothers and the courts' willingness to ignore mothers' conscious or overt beliefs and actions in favor of a loose psychoanalyzing, which freely asserts that even the best-intentioned mothers do not know their own insidious wishes or behaviors (Johnston, 2005).

A widely disseminated example of this blending of the new "reformulation" with original PAS concepts was the lengthy publication issued by the Appellate Division of the Supreme Court of the State of New York in its "Law Guardian Reporter" and republished by the New York State Bar Association, entitled "Father? What Father? Parental Alienation and its Effect on Children" (Steinberger, 2006). While pointedly renouncing any reliance on PAS, the author's discussion of PA sounds suspiciously similar, and it cites the PAS literature:

Even without deliberately intending to interfere with the other parent's relationship, a parent whose view of the other is 'colored,' might 
naturally 'selectively perceive and distort' the child's relationship with the non-custodial parent (citation omitted).

'When 5-year-old Sally expressed a wish to call her father on the phone and tell him how she learned to jump rope that day, her mother withdrew into sullen anger. Inexplicably to Sally, her mother was 'too tired' to read her [the] usual bedtime story that evening'... because the punishing message is typically unspoken [it] is ... impossible to be spoken about, which makes it even more pernicious and difficult to detect (citation omitted).

Denigration may be used by making moral judgments against the target parent's values, lifestyle, choice of friends, career or financial or relational successes or failures in life (citing Clawar \& Rivlin, 1991). These criticisms are often 'insidious, occurring over a period of time with different degrees of intensity but always powerful. Like the wearing away of a stone constantly assaulted by waves, the child's perception of the target parent changes from its original, more positive, view finally conforming to the programming parent's opinions and sentiments. (i.d.) In such cases, the effect is almost irreversible. These beliefs become so ingrained that the parent who created them no longer has to promote [them]. They have been given life within the child's own mind. So much so, that the parent may honestly report that he or she is not actively doing anything by word or deed to thwart the target parent's relationship with the child (citation omitted).

(Steinberger, 2006, pp. 7-8)

This description makes extensive use of PAS terminology, including "programming" and "target parent," as well as concepts such as the idea that mothers unconsciously and subtly undermine their children's relationships with their noncustodial fathers. Similarly, in the case previously mentioned that this author litigated in 2005, the forensic evaluator who had in 2002 testified firmly in favor of PAS as an explanation for the child's sexual abuse allegations against her father (denying then that it was a "controversial" theory), testified in 2005 that PAS was no longer appropriately relied on in forensic psychology and that PA was the more legitimate theory. However, she did not identify any difference in her interpretation of the facts or her recommendation as a result of the new label (Alford, 2003). In short, the reality is that whatever some researchers may say about the differences between PAS and $\mathrm{PA}$, in practice, PA is rarely understood to be different. Indeed, some proponents of alienation theory simply cite to both PAS and PA without distinction (The Custody Center, n.d., line 1-2).

Gardner himself noted that some evaluators used the term "parental alienation" instead of PAS in order to avoid the attacks that reference to a "syndrome" invites. Gardner opposed this practice, arguing that PAS is a far more severe and entrenched problem than mere "parental alienation" (Gardner, 2002).

While taking pains to distance themselves from Gardner's belief that pathological alienation is caused solely by bad custodial parents, Johnston 
and her followers (Johnston, Walters \& Olesen, 2005) nonetheless also continue to emphasize the unconscious or subconscious factors that they believe fuel mothers' alienating behaviors. For instance, like PAS proponents, Johnston and her collaborators assert the counterintuitive position that a mother's "warm, involved" parenting can powerfully fuel alienation in a child. The evalutor in the case discussed previously made the same point. This element of PAS theory has provided one of the many ways that PAS proponents successfully (and counterintuitively) attack warm, loving protective mothers' parenting. Johnston and Kelly (2001) also, like Gardner, state that a parent could "unconsciously" denigrate the other parent to the child "as a consequence of their own deep psychological issues" which cause them to "harbor deep distrust and fear of the ex-spouse."

Consistent with this implicit skepticism toward women's fear of their ex-spouses, Johnston and her collaborators have propounded ideas that undermine courts' recognition of abuse or its valid implications. For instance, in an early article, Kelly and Johnston (2001) explicitly pathologized the "aligned" parent who "fervently believes that the rejected parent is dangerous to the child in some ways; violent, physically or sexually abusive, or neglectful" (p. 258). They characterized the mother's pursuit of legal protections and other means of seeking safety as a "campaign to protect the child from the presumed danger [which] is mounted on multiple fronts [including] restraining orders" (p. 258).

In their more recent PA publications, Johnston and collaborators (Johnston, Walters, \& Olesen, 2005) are less blunt, but they continue to conflate alienation with the logical results of abuse. For instance, they describe the alienated child as an unhealthy child who "lose[s] their emerging sense of self and their capacity for realistic judgment, become[s] psychologically enmeshed, and form[s] a pathological alliance with one parent against the other" (p. 210). While in some contexts, Johnston and her collaborators take pains to state that a child who is "estranged" from an abusive parent is not, in their definition, "alienated" or "pathologically" aligned (Johnston, 2005; Kelly \& Johnston, 2001), they also sometimes use the terms "alienation" and "rejection of a parent" when describing all children who are hostile to a parent without distinguishing the reasons (Johnston, 2004, 2005). Perhaps more importantly, in discussing the damage caused by alienation they have conflated children who have been alienated by the pernicious influence of a favored parent with those who have suffered or witnessed abuse, which may have caused both the psychological damage and the child's estrangement (i.d.).

Tempest in a Teapot. It is notable that Johnston's own research studies have found that even among the children who rejected a parent (i.e., were found to be alienated), all had multiple reasons for their hostility. These reasons included negative behaviors by the hated parent, such as child abuse or inadequate parenting, or the children's own developmental or personality 
difficulties (Johnston, 2005; Johnston, Waters, \& Olesen, 2005). Moreover, some of the children who lacked independent reasons had been alienated by abusive fathers from their non-offending mothers (Johnston, 2005). The characterization of all of these children as victims of alienation rather than separating out those whose alienation is a natural and appropriate response to a dysfunctional parent, or the product of a larger pattern of abuse, inevitably contributes to the obscuring of abuse as well as a disproportionate and unjustified concern with parents' alienating behaviors.

Johnston (2005) stated that their research indicated that child abuse in itself does not cause children's alienation and that alienation occurs only when there is a combination of factors, including "critical incidents of child abuse and/or lack of warm, involved parenting" by the rejected parent in conjunction with the aligned parent's warm parenting and alienating behaviors. Even if this rather surprising conclusion is accurate, the overall emphasis on alienation, rather than the abuse, both as the subject of analysis and as the explanation for children's problems, unfortunately, contributes to the field's continued privileging of alienation as the dominant concern over abuse.

Perhaps more fundamentally, Johnston's own research indicates that only "a small proportion of children" exposed to alienating conduct by a parent vehemently resist or refuse contact with one parent (Johnston, 2005). Indeed, Johnston's research indicates that even where the vast majority of both parents used alienating behaviors, only $6 \%$ of children were "extremely rejecting" and only $20 \%$ "showed indication of being consistently negative" (i.d.). Most notably, even these children had multiple reasons for their hostility, including child abuse or other negative behaviors by the rejected parent (Johnston, 2005).

Finally, to date there is little or no empirical evidence supporting clinicians' assertions that alienated children will be significantly damaged (Johnston \& Kelly, 2004b, p. 84). Indeed, Johnston and Kelly forthrightly state that "there are no systematic long-term data on the adjustment and well-being of alienated compared to non-alienated children so that long-term prognostications are merely speculative" (p. 84). It is an article of faith among many evaluators and courts that alienation causes disastrous psychological harm to children. However, this assumption may be incorrect. Wallerstein, whose original study of children of divorce first noticed children's pathological "alignments" with one parent after divorce, found in her follow-up study that children's hostility toward the other parent was temporary and resolved of its own accord, mostly within one or two years (Bruch, 2001; Wallerstein, Lewis, \& Blakeslee, 2000).

For all these reasons - its relatively rare emergence even in antagonistic divorcing families, the research's indication that much so-called alienation is really a function of abuse, and the likelihood that much alienation is transient-parental alienation is a tempest in a teapot. 
Thus, while PAS is increasingly (but not entirely) relegated by thoughtful analysts to the past, PA or comparable approaches continue to dominate forensic evaluation and related scholarship. This continued focus on alienation and alienated children remains a destructive trend in custody evaluation and litigation. The reformulated theory continues to validate the idea that mothers are hostile to fathers for reasons that are not reality-based; that their unconscious wishes and hostilities can be known by courts, even in contradiction to their conscious and objectively measurable actions; and, that even children who have been subjected to abuse (of themselves or of their mothers) need to be protected from alienating behaviors by their protective parent. This does little to abate the misuse of alienation theory in custody litigation that furthers abusers' power over children and mothers at the cost of both children's and mothers' needs for safety and for healthy and secure parent-child relationships that can flourish free of abusive intervention and control.

\section{CONCLUSION}

It is undeniable that a parent can undermine a child's relationship with the other parent. That some children-especially during a divorce-may develop a strong hostility toward a parent who does not "objectively" warrant such hostility is also likely. However, Johnston, Walters, \& Olesen (2005) have found that "it is remarkable that so few children were rejecting of a parent, especially in the face of their parents' negative attitudes and behaviors toward one another. These findings support commonly held views that pre-adolescent children's ties to both their parents are remarkably resilient in the context of family conflict and divorce" (p. 206). In other words, while parents' inappropriate denigration of each other is common in custody litigation, pathological and destructive alienation is hard to achieve and rare. In light of the undeniable history of the misuse of alienation theory to negate and trivialize real abuse and the theory's undermining of children's safety in custody and visitation with abusive parents, the continued emphasis on alienation in custody cases where abuse is alleged is ill-advised. Even the most responsible and thoughtful analyses tend to inappropriately marginalize and discount abuse, and unfortunately, many court evaluations do not meet this level of professional competence or humility. Given the reality that parental alienation is far more often used in practice to deny real abuse than to actually reduce psychological harm to children, courts and evaluators should be wary of alienation claims and entertain them-at mostonly when there is actual concrete evidence of alienating behavior and results. Alienation claims and assessments, if considered at all, should be de-linked from a parent's allegations of abuse and concomitant protective actions, and should stand or fall on their own. ${ }^{15}$ 


\section{NOTES}

1. In another article in the companion volume to this one, I bring this perspective to bear on Leslie Drozd and Nancy Olesen's Decision Tree approach to evaluation of alienation and abuse claims (see Meier, in press).

2. A growing movement to differentiate between different "types" of domestic violence contends that conflict-based and control-based intimate violence are entirely different phenomena, and that, whereas women engage in conflict-based violence almost equally with men, intimate violence which is embedded in a pattern of the abuser's power and control over the victim is predominantly male against female (Johnson, 2005). For purposes of this article, my references to "abusers" and "domestic violence" refer to the control-based paradigm of abuse.

3. One of his first books contains a number of compassionate and seemingly constructive comments on what children need in the context of divorce, without the demonizing of mothers that characterizes his later work on PAS. (Gardner, 1976).

4. PAS' prevalence can be seen as a testament to the loose evidentiary standards in custody courts. Gardner's website touted over 50 cases which he asserted held it admissible, and custody evaluators and lawyers have relied on these assertions and string cites to support their PAS arguments. (Licata v. Licata, 2003) However, a thorough review of the cases cited on Gardner's website revealed that not one of the cited cases was a precedent-bearing decision ruling PAS admissible. Four trial level decisions explicitly ruled it admissible, but several lack any published opinion, and the appeal of each decision resulted in no ruling on the PAS issue. (Hoult, 2006).

5. Even as of the publication of this article, as PAS has fallen out of favor with scientificallyoriented evaluators and courts, it continues to gain in popular and political recognition. Roughly 16 states' governors have issued proclamations concerning the purported problem of PAS, http://paaous.com/about.asp (last visited May 27, 2009). Moreover, the media continues to popularize PAS in light of scandals such as Alex Baldwin's invocation of PAS to rationalize his widely discussed recorded abusive phone message to his teenage daughter. (de Moraes, 2007; http://transcripts.cnn.com/ TRANSCRIPTS/0704/24/ng.01.html).

6. Although judges routinely adopt GAL and evaluator recommendations which disbelieve abuse allegations and favor increased paternal access, this author has now heard of several cases where the GAL or evaluator found abuse concerns to be valid and recommended restricted paternal access, but the judge rejected the recommendation.

7. While many litigants may lack the knowledge or resources to counter the errors PAS propagates, even where litigants directly challenge these myths and misconceptions, trial courts may ignore the valid research in favor of their preferred "expert's" largely unfounded opinion. This is what occurred in this author's case mentioned above, when the judge ignored the expert testimony which corrected those misconceptions and educated the court about the realities of child sexual abuse. Notably, the trial court's failure to protect the child, indirectly fueled by the court evaluator's suggestion of parental alienation, was roundly chastised by the Court of Appeals which reversed without remand, based both on the trial judge's failure to apply the correct legal standard and his ignoring of several expert recommendations to ensure visits were supervised in light of the record evidence. (Wilkins v. Ferguson, 2005).

8. This statement is not intended to suggest that every time a court awards joint or sole custody to a batterer that it is necessarily the wrong decision. There are undoubtedly occasional cases where even a parent who has committed some violence may, sadly, be the better parent, e.g., where the other parent is dysfunctional enough to impair the children's daily care or a genuine parental connection. (Engh $v$. Jensen, 1996). While some domestic violence advocates assert that a batterer should never have custody and some even suggest that all visitation should be eliminated, in my view, the spectrum of what legally constitutes "abuse" is far too wide, and the range of other kinds of dysfunctions among parents (and needs of children) too varied, to justify such an absolute rule. However, the rare case when an abuser may be truly better for the children than the victim should be sharply distinguished from the far more common phenomenon of courts' relying on the invalid PAS theory, over-valuing joint parenting despite abuse, failing to do meaningful fact-finding, failing to recognize the link between adult abuse and bad parenting, or imposing gender biased decisions (Stop Family Violence, 2007).

9. Numerous gender bias task forces have found that court personnel harbor gender biased beliefs and attitudes about the comparative credibility and plausibility of women's and men's testimony and stories. (Czapanskiy, 1995; Massachusetts Supreme Judicial Court, 1990). 
10. Though the findings that a majority of contested custody cases involve allegations of a history of partner violence have been remarkably consistent across researchers and studies, observers may not share the same assumptions about who the primary aggressors are. One recent study by Johnston (2005) indicated that men commit a larger percentage of such abuse, but women also perpetrate some ( $40 \%$ of fathers and $15 \%$ of mothers had perpetrated "substantiated" domestic violence; approximately equal percentages had committed substantiated child abuse [15\%]). Analyses by Johnson (2005) and others (Johnson \& Leone, 2005; Pence \& Dasgupta, 2006) have recently suggested that some types of domestic abuse are gender-equal, but that the vast majority of those who seek legal protection are women victimized by controlling and patriarchal men. Scholars such as Stark (2007b) have long argued that battering or abuse should not be defined solely by violence - but rather, by "power and control" behaviors aimed at dominating and oppressing a partner and depriving her of fundamental liberty rights. Insofar as Johnson's analysis seems to suggest that many women do indeed use minor physical violence (some but not all of which is defensive or reactive) expressively rather than as a means of dominating their partner, it is becoming essential for both research and courts to assess not only for acts of physical violence but also for power and control behaviors which are used to dominate and terrify the partner (Ver Steegh, 2005). It would be interesting to know whether, with this information, Johnston's data would demonstrate that it is women who are fearful and being controlled and dominated, while men may be the recipients of minor violence but are neither afraid nor controlled. If so, the policy question of whether violence alone is what we most abhor, or whether power and control/domination is the more destructive behavior, will remain to be decided by legislators and courts. Being clear that we need to examine domination and control dynamics is a critical first step.

11. The commonality of alienation findings against mothers who allege abuse and the courts' willingness to implement PAS' prescriptions to send children to the fathers they fear, compared to some courts' inaction in the face of children's hatred of their mother after being placed in the care of a father who the mother alleged was abusive, lends credence to the gender bias hypothesis.

12. While joint legal custody and joint physical custody are distinct concepts, it appears, based on my own experience and that of others around the country, that most courts' preferences extend to both. However, some courts are also beginning to call "joint physical custody" what used to be called "sole custody and visitation." Perhaps it is clearest to say that courts seek to avoid depriving a father of "custody" in whatever ways they can, including through both substantive awards of parenting time and through labels. The new trend toward replacing the language of "custody" with the language of "parenting time" is another example of courts' discomfort with selecting "winners" and "losers" among parents (Florida Senate, 2009).

13. Fathers' rights groups vigorously dispute this and tout the statistical claim that $85-95 \%$ of cases result in maternal custody. www.fathersandfamilies.org/site/about.php (last visited May 29, 2007) ("the courts award physical custody of children to their fathers in only about $9 \%$ of cases. Shared physical custody is even more unusual.") (Thompson \& Sacks, 2002). However, the studies cited do not distinguish between cases settled by the parties and those adjudicated by the courts. It should be no surprise that the vast majority of cases in which the parties work out an agreement result in maternal custody, given that in the vast majority of intact families the mother is still the primary caretaker of the children (Tanfer \& Mott, 1997; Grief, 1990). Invoking the data on total outcomes of divorce to represent how judges adjudicate cases is completely misleading-because it actually reflects how parties resolve cases by agreement, not how judges decide cases. The data on adjudications, as noted previously, indicate that judges prefer custody to fathers or joint custody to maternal sole custody.

14. However, as of this writing, the American Psychological Association and state and local bar associations continue to sponsor workshops on and disseminate materials about PAS. See http://www.apa.org/ ce/workshopssat.html; http://books.apa.org/books.cfm?id=431747A\&toc=yes.

15. See Meier, J. (2009) and Meier, J. (in press), for a more detailed programmatic prescription for courts' considerations of alienation claims.

\section{REFERENCES}

Alford, N.M. (2003). Report of Court-Ordered Observations, dated Jun 16, 2003, in Wilkins v. Ferguson, DR-757-01 (on file with author).

American Psychological Association Presidential Task Force on Violence and the Family (APA). (1996). Violence and the family: Report of the APA Presidential Task Force. Washington, DC: American Psychological Association. 
Arizona Coalition Against Domestic Violence. (2003). Battered Mothers' Testimony Project: A buman rights approach to child custody and domestic violence. Retrieved June 2003, from http://www.azcadv.org/PDFs/FS-BMTP\%20report.pdf.

Associated Press. (2006, September 2). A girl taken to Canada ... by her mother... will now live with her father. The Philadelphia Inquirer, p. B06.

Bancroft, L., \& Silverman, J. (2002). The batterer as parent: Addressing the impact of domestic violence on family dynamics. Thousand Oaks, CA: Sage.

Barr, C.W. (2006, June 11). For fathers, a chance to improve, become mentors to their sons at Pr. George's Conference, about 100 gather to be better role models. The Washington Post, p. C09.

Boorstein, M. (2006). Fatherhood program offers a fresh start to D.C. dads: Goal is to strengthen families, renew bonds. The Washington Post, p. T1.

Bowermaster, J.M. (2002). Legal presumptions and the role of mental health professionals in child custody proceedings. Duquesne Law Review, 4O(2), 265-311.

Bruch, C.S. (2001). Parental Alienation Syndrome and Parental Alienation: Getting it wrong in child custody cases. Family Law Quarterly, 35, 527-552.

C.J.L. v. M.W.B., 879 So.2d 1169 (Ala.Civ.App. 2003).

Clawar \& Rivlin, Children Held Hostage: Dealing with Programmed and Brainwashed Children, American Bar Association Section on Family Law (1991).

Czapanskiy, K. (1993). Domestic violence, the family, and the lawyering process: Lessons from studies on gender bias in the courts. Family Law Quarterly, $27(2), 247-278$.

Daghir V. Daghir, 82 A.D. 2d 191 (2d Dep't, 1981), aff'd, 56 N.Y.2d 938 (1982).

Dallam, S. (1998). Dr. Richard Gardner: A review of his theories and opinions on atypical sexuality, pedophilia, and treatment issues. Treating Abuse Today, $8(1), 15-22$.

Dalton, C., Carbon, S., \& Olesen, N. (2003). High conflict divorce, violence, and abuse: Implications for custody and visitation decisions. Juvenile and Family Court Journal, 54(4), 11-33.

Dalton, C., Drozd, L., \& Wong, F. (2006). Navigating Custody and Visitation Evaluations in Cases with Domestic Violence: A Judge's Guide. National Council of Juvenile \& Family Court Judges \& State Justice Institute.

De Moraes, L. (2007, April 28). Alec Baldwin, still angry at the wrong person. The Washington Post, p. C01.

Drozd, L.M., \& Olesen, N.W. (2004). Is it abuse, alienation, and/or estrangement? A decision tree. Journal of Child Custody, 1(3), 65-106.

Ducote, R. (2002). Guardians ad litem in private custody litigation: The case for abolition. Loyola Journal of Public Interest Law, 3, 106-151.

Emery, R.E., Otto R.K., \& O'Donohue, W.T. (2005). A critical assessment of child custody evaluations: Limited science and a flawed system. Psychological Science in the Public Interest, 6(1), 1-29.

Engh v. Jensen, 547 N.W.2d 922 (N. Da. 1996).

Faller, K.C. (1998). The Parental Alienation Syndrome: What is it and what data support it?. Child Maltreatment, 3(2), 100-115.

Faucher v. Bitzer, 2002 WL 432750 (Ark. App., 2002).

Finkelhor, D. (1986). A sourcebook on child sexual abuse. Thousand Oaks, CA: Sage Publications. 
Florida Senate (2009). Bill\#0904: Relating to Parental Responsibility and Timesharing, retrievable at http://flsenate.gov/cgi-bin/view_page.pl?Tab=session\& Submenu=1\&FT=D\&File=sb0904er.html\&Directory=session/2009/Senate/bills/ billtext/html/ (last visited May 27, 2009)

Gardner, R.A. (1976). The boys and girls book about divorce. New York, NY: Jason Aaronson, Inc.

Gardner, R.A. (1987). The Parental Alienation Syndrome and the differentiation between fabricated and genuine child sex abuse. Cresskill, NJ: Creative Therapeutics.

Gardner, R.A. (1991). Sex abuse bysteria: Salem Witch Trials revisited. Cresskill, NJ: Creative Therapeutics.

Gardner, R.A. (1992a). The Parental Alienation Syndrome: A guide for mental bealth and legal professionals. Cresskill, NJ: Creative Therapeutics.

Gardner, R.A. (1992b). True and false accusations of child sex abuse. Cresskill, NJ: Creative Therapeutics.

Gardner, R.A. (2002). Parental Alienation Syndrome vs. Parental Alienation: Which diagnosis should Evaluators use in child custody disputes?. The American Journal of Family Therapy, 30(2), 93-115.

Gould, J.W. (2006). Conducting scientifically crafted child custody evaluations (2nd Ed.). Sarasota, FL: Professional Resource Press.

Grief, G.L. (1990). Ten myths about the fathers' childhoods, marriages, and custody arrangements. In The daddy track and the single father. Lexington, MA: Lexington Books.

Hanson v. Spolnik, 685 N.E.2d 71 (Ind. App. 1997).

Harris, H.R. (2006). Men discuss finding time for fatherhood communication with children stressed. The Washington Post, Section T3.

Herman, J. (1992). Trauma and recovery. New York: Basic Books.

Hoult, J. (2006). The evidentiary admissibility of parental alienation syndrome: Science, law and policy. Children's Legal Rights Journal, 26(1), 1-61.

Ignatiuk v. Ignatiuk, 2006 WL 933490 (Ark. App., 2006).

In re Interest of T.M.W., 553 So. 2d 260 (Fla. App. 1 Dist. 1989).

In re J.C., 2007 WL 4239288 (Cal. App. 2 Dist. 2007).

In re Marriage of Arthur, 2004 WL 1732709 (Cal. App.3 Dist. 2004).

In re Marriage of Bates, 819 N.E.2d 714 (Ill. 2004).

In re Marriage of McCord, 2003 WL 22005755 (Wis. App. 2003).

In re Marriage of Rosenfeld, 524 N.W.2d 212 (Ia. App. 1994).

J.F. v. L.F., 694 N.Y.S.2d 592 (N.Y. Fam. Ct. 1999).

Jaffe, P.G., Crooks, C.V., \& Poisson, S.E. (2003). Common misconceptions in addressing domestic violence in child custody disputes. Juvenile and Family Court Journal, 54(4), 57-67.

Johnson, M.P. (2005). Apples and oranges in child custody disputes: Intimate terrorism vs. situational couple violence. Journal of Child Custody, 2(4), 43-51.

Johnson, M.P., \& Leone, J.M. (2005). The differential effects of intimate terrorism and situational couple violence: Findings from the National Violence Against Women Survey. Journal of Family Issues, 26(3), 322-349.

Johnston, J.R. (1994). High-conflict Divorce. Future of Children, 4, 165-182. 
Johnston, J.R. (2005). Children of divorce who reject a parent and refuse visitation: Recent research and social policy implications for the alienated child. Family Law Quarterly, 38, 757-775.

Johnston, J.R., \& Campbell, L.E.G. (1988). Impasses of divorce: The dynamics and resolution of family conflict. New York: The Free Press.

Johnston, J.R., \& Kelly, J.B. (2004a). Rejoinder to Gardner's "Commentary on Kelly and Johnston's 'The alienated child: A reformulation of Parental Alienation Syndrome." Family Court Review, 42(4), 622-628.

Johnston, J.R., \& Kelly, J.B. (2004b). Commentary on Walker, Brantley, and Rigsbee's (2004) 'A critical analysis of Parental Alienation Syndrome and its admissibility in the family court.' Journal of Child Custody, 1(4), 77-89.

Johnston, J.R., Walters, M.G., \& Olesen, N.W. (2005). Is it alienating parenting, role reversal or child abuse? A study of children's rejection of a parent in child custody disputes. Journal of Child Custody, 5, 191-218.

Kelly, J.B., \& Johnston, J.R. (2001). The alienated child: A reformulation of Parental Alienation Syndrome. Family Court Review, 39(3), 249-266.

Leving, J.M., \& Sacks, G. (2007). New Column: Equal Rights Amendment yes, 'Women's Equality Amendment' no. The Courier-Journal (Louisville, KY). Available at http://glennsacks.com/blog/?p=691.

Lewis-O'Connor, A., Sharps, P.W., Humphreys, J., Gary, F.A., \& Campbell, J. (2006). Children exposed to intimate partner violence. In M.M. Feerick \& G.B. Silverman (Eds.), Children exposed to violence (pp. 3-28). Baltimore: Paul H. Brookes Publishing Co.

Licata v. Licata (2003). Brief and Appendix for Defendant-Respondent, Docket No. A-00660-02T3, Superior Court of New Jersey Appellate Division, June 1, 2003.

Linder v. Johnson, 2006 WL 3425021 (Ark. App., 2006).

Massachusetts Supreme Judicial Court (1990). Gender bias study of the court system in Massachusetts. New England Law Review, 24, 745-859.

Meier, J. (2003). Domestic violence, child custody and child protection: Understanding judicial resistance and imagining the solutions. American University Journal of Gender, Social Policy \& the Law, 11(2), 657-731.

Meier, J. (2009, January). Parental alienation syndrome and parental alienation: Research reviews. Harrisburg, PA: VAWnet, a project of the National Resource Center on Domestic Violence/Pennsylvania Coalition Against Domestic Violence. Retrieved July 13, 2009, from http://www.vawnet.org

Meier, J. (in press). Getting Real about Abuse and Alienation: A Critique of Drozd and Olesen's Decision Tree. Journal of Child Custody.

Montes, S.A.P. (2006, April 18). Md. man gets to say, 'Daddy does love you.' The Washington Post, p. B01.

Morrill, A.C., Dai, J., Dunn, S., Sung, I., \& Smith, K. (2005). Child custody and visitation decisions when the father has perpetrated violence against the mother. Violence Against Women, 11(8), 1076-1107.

Myers, Berliner, Briere, Hendrix, Jenny, \& Reid (Eds.). (2002). The APSAC handbook on child maltreatment (2nd Ed.). Thousand Oaks, CA: Sage.

Neustein, A., \& Goetting, A. (1999). Judicial responses to the protective parent's complaint of child sexual abuse. Journal of Child Sexual Abuse, 8(4), 103-122. 
Neustein, A., \& Lesher, M. (2005). From madness to mutiny: Why mothers are running from the family courts-and what can be done about it. Lebanon, $\mathrm{NH}$ : Northeastern University Press.

N.K. v. M.K., 17 Misc.3d 1123(A), 2007 WL 3244980 (N.Y. Sup. 2007).

Oates v. Oates, 2008 (Orders on file with author).

Palazzolo v. Mire, 2009 WL 103957 (La. App. 4 Cir., 2009).

Pearson, J. (1993). Ten myths about family law. Family Law Quarterly, 27(2), 279-299.

Pence, E., \& Das Dasgupta, S. (2006). Re-examining 'battering': Are all acts of violence against intimate partners the same? Retrieved July 12, 2009, from http:// www.praxisinternational.org/pages/library/BattererInternational.asp

People v. Fortin, 289 A.2d 590 (N.Y. App. Div. 2001).

People v. Sullivan, 2003 WL 1785921 (Cal. App. 6 Dist. 2003).

Ragland, E.R., \& Fields, H. (2003a). Parental Alienation Syndrome: What professionals need to know. National Center for Prosecution of Child Abuse (NCPCA) Update Newsletter, 16(6).

Ragland, E.R., \& Fields, H. (2003b). Parental Alienation Syndrome: What professionals need to know. National Center for Prosecution of Child Abuse (NCPCA) Update Newsletter, 16(7).

Rebar v. Ghaben, 2008 (documents on file with author).

Ruggiero v. Ruggiero, 819 A.2d 864 (Conn. App., 2003).

Sharp v. Keeler, 99 Ark. App. 42, 256 S.W.3d 528. (2007).

Sharp v. Keeler, 103 Ark. App. 233. (2008).

Shuman, D. W. (2002). The role of mental health experts in custody decisions: Science, psychological tests, and clinical judgment. Family Law Quarterly, 36, 135-162.

Silverman, J.G., Meesh, C.M., Cuthbert, C.V., Slote, K., \& Bancroft, L. (2004). Child custody determinations in cases involving intimate partner violence: A human rights analysis. American Journal of Public Health, 94(6), 951-953.

Smith, R., \& Coukos, P. (1997). Fairness and accuracy in evaluations of domestic violence and child abuse in custody determinations. The Judges' Journal, 38-56.

Snyder v. Cedar, 2006 Conn. Super. LEXIS 520. (2009).

Stahly, G.B., Krajewski, L., Loya, B., Uppal, K., German, G., Farris, W., et al (2004). Protective mothers in child custody disputes: A study of judicial abuse. In Disorder in the courts: Mothers and their allies take on the family law system. (a collection of essays). Retrieved July 13, 2009, from http://www.leadership council.org/1/pas/dv.html

Stark, E. (1995). Representing woman battering: From Battered Woman Syndrome to coercive control. Albany Law Review, 58(4), 973-1026.

Stark, E. (2007a). Electronic communication with Joan Meier, May, [date?].

Stark, E. (2007b). Coercive control: The entrapment of women in personal life. London: Oxford University Press.

Steinberger, C. (2006, Spring, Fall). Father? What Father? Parental Alienation and its effect on children. N.Y. State Bar Association Family Law Review. Available at www.drhavlicek.com

Stop Family Violence. (2007). Petition in accordance with Inter-American Commission on Human Rights (Human Rights Petition). Retrieved November 26, 2008, from http://www.stopfamilyviolence.org/pages/304 
Tanfer, K., \& Mott, F. (1997). The Meaning of Fatherhood. Retrieved July 13, 2009, from http://fatherhood.hhs.gov/CFSForum/apenc.htm

The Custody Center (n.d.). What is Parental Alienation Syndrome (PAS)? Retrieved April 30, 2009 from www.custodycenter.com/PAS

The Washington Post. (2006, February 5), Nation in Brief, p. A.08 (Lillington, N.C. archive excerpt-two girls reunited with their father after being abducted more than six years ago by their mother).

Thoennes, N., \& Tjaden, P. (1990). The extent, nature, and validity of sexual abuse allegations in custody/visitation disputes. Child Abuse and Neglect, 14, 151-163.

Thompson, D., \& Sacks, G. (2002). Fathers bear the brunt of gender bias in family courts. Insight. Retrieved July 13, 2009, from http://www.glennsacks.com/ fathers_bear_the.htm

Trocme, N., \& Bala, N. (2005). False allegations of abuse and neglect when parents separate. Child Abuse and Neglect, 29(12), 1333-1345.

Turner v. Benson, 953 S.W.2d 596. (Ark. App. 1997).

USA TODAY Snapshots. (2007, January 12). The Importance of Fatherhood (Source: The National Fatherhood Initiative), p. A1.

Ver Steegh, N. (2005). Differentiating types of domestic violence: Implications for child custody. Louisiana Law Review, 65(4), 1379-1431.

Waller, G. (Producer). (2001). Small Justice: Little Justice in America' Family Courts [Motion Picture]. United States: Intermedia Inc.

Wallerstein, J.S., \& Kelly, J.B. (1976). The effects of parental divorce: Experiences of the child in early latency. American Journal of Orthopsychiatry, 46(1), 20-32.

Wallerstein, J.S., \& Kelly, J.B. (1980). Surviving the break-up: How parents and children cope with divorce. New York, NY: BasicBooks.

Wallerstein, J.S., Lewis, J.M., \& Blakeslee, S. (2000). The unexpected legacy of divorce: A 25 Year landmark study. New York: Hyperion Books.

Wiederholt v. Fischer, 485 N.W.2d 442. (Wisc. 1992).

Wilkins v. Ferguson (2003). Order, Case No. 01DR-757, IF 2261-02, August 5, 2003 (D.C.).

Wilkins v. Ferguson, 928 A.2d 655 (D.C 2007).

Wood, C. (1994). The Parental Alienation Syndrome: A dangerous aura of reliability. Loyola of Los Angeles Law Review, 27, 1367-1415. 